\title{
Osteoimmunology of Bone Loss in Inflammatory Rheumatic Diseases
}

\author{
Fabienne Coury ${ }^{1,2,3}$, Olivier Peyruchaud ${ }^{1,2}$ and Irma Machuca-Gayet ${ }^{1,2 *}$ \\ ${ }^{1}$ INSERM, UMR1033 LYOS, Lyon, France, ${ }^{2}$ University Claude Bernard Lyon I, Lyon, France, ${ }^{3}$ Department of Rheumatology, \\ Lyon Sud Hospital, Lyon, France
}

\section{OPEN ACCESS}

Edited by:

Claudine Blin-Wakkach,

UMR7370 Laboratoire de Physio Médecine Moléculaire (LP2M), France

Reviewed by:

Patrizia D'Amelio,

University of Turin, Italy

Yong-Gil Kim,

University of Ulsan College of

Medicine, South Korea

Mascha Koenen,

University of Ulm, Germany

*Correspondence:

Irma Machuca-Gayet irma.machuca-gayet@inserm.fr orcid.org/0000-0002-3010-9774

Specialty section:

This article was submitted to Inflammation,

a section of the journal

Frontiers in Immunology

Received: 08 January 2019 Accepted: 12 March 2019

Published: 03 April 2019

Citation:

Coury F, Peyruchaud $O$ and Machuca-Gayet I (2019) Osteoimmunology of Bone Loss in Inflammatory Rheumatic Diseases.

Front. Immunol. 10:679.

doi: 10.3389/fimmu.2019.00679
Over the past two decades, the field of osteoimmunology has emerged in response to a range of evidence demonstrating the reciprocal relationship between the immune system and bone. In particular, localized bone loss, in the form of joint erosions and periarticular osteopenia, as well as systemic osteoporosis, caused by inflammatory rheumatic diseases including rheumatoid arthritis, the prototype of inflammatory arthritis has highlighted the importance of this interplay. Osteoclast-mediated resorption at the interface between synovium and bone is responsible for the joint erosion seen in patients suffering from inflammatory arthritis. Clinical studies have helped to validate the impact of several pathways on osteoclast formation and activity. Essentially, the expression of pro-inflammatory cytokines as well as Receptor Activator of Nuclear factor $\kappa B$ Ligand (RANKL) is, both directly and indirectly, increased by $T$ cells, stimulating osteoclastogenesis and resorption through a crucial regulator of immunity, the Nuclear factor of activated T-cells, cytoplasmic 1 (NFATc1). Furthermore, in rheumatoid arthritis, autoantibodies, which are accurate predictors both of the disease and associated structural damage, have been shown to stimulate the differentiation of osteoclasts, resulting in localized bone resorption. It is now also evident that osteoblast-mediated bone formation is impaired by inflammation both in joints and the skeleton in rheumatoid arthritis. This review summarizes the substantial progress that has been made in understanding the pathophysiology of bone loss in inflammatory rheumatic disease and highlights therapeutic targets potentially important for the cure or at least an alleviation of this destructive process.

\section{Keywords: inflammatory rheumatic diseases, rheumatoid arthritis, spondyloarthritis, bone erosion, inflammatory} bone loss, osteoclast

\section{INTRODUCTION}

The close relationship between the immune and bone systems has long been noted since pioneering work on soluble immune cell-derived osteoclast-activating factors performed in the early 1970 s $(1,2)$ and was termed osteoimmunology (3). The most significant osteoimmunological example arose from the observation of osteoclast-mediated bone loss in inflammatory rheumatic diseases. Inflammatory rheumatic diseases encompass more than 100 heterogeneous multisystem disorders which can affect joints and lead to disability. However, rheumatoid arthritis (RA) and the spondyloarthritis group $(\mathrm{SpA})$ are the most common inflammatory rheumatic diseases that preferentially affect joints and cause tenderness, swelling, and destruction of joints. Consequently, in this review, we will confine the term "inflammatory rheumatic diseases" to these particular 
diseases. SpA, also termed "seronegative" as they do not produce rheumatoid factor nor the anti-citrullinated peptide antibodies (ACPA) observed in RA, represent a group of diseases with common genetic and clinical features, including ankylosing spondylitis (AS), reactive arthritis, psoriatic arthritis (PsA), and SpA associated with inflammatory bowel disease.

RA is considered to be the prototype of destructive inflammatory arthritis with bone loss at sites of articular and peri-articular inflammation. SpA also causes inflammation of the axial skeleton and extra-articular entheses leading to not only bone degradation but also to ectopic bone formation-which in some cases can even lead to bony ankylosis of the joint. Genetic and experimental evidence has associated the activation of IL23-IL17 axis with inflammation and entheseal new bone. The ectopic bone formation aspect of SpA will not be discussed further, as herein review focus is restricted to bone loss, formation is reviewed elsewhere (4). This dissimilarity in the anatomical sites of bone affected and in bone formation patterns highlights the differences in pathophysiological mechanisms involved in these conditions.

Herein, we briefly highlight the key concepts and recent advances in the osteoimmunology field within the context of bone loss in inflammatory rheumatic diseases.

\section{DIFFERENTIAL BONE LOSS IN INFLAMMATORY RHEUMATIC DISEASES}

Three forms of bone loss have been identified in patients with inflammatory rheumatic diseases: localized bone loss with erosion, periarticular osteopenia, and generalized bone loss (Table 1).

Although cortical bone erosion revealed by radiography is commonly considered to be a hallmark of RA, it can also be observed in SpA as well as other rheumatic diseases such as gout or osteoarthritis - with a distinct radiographic appearance and location. Erosion begins early in inflammatory rheumatic diseases, even prior to the clinical onset of arthritis: erosion has been described in ACPA-positive healthy subjects (5). For long considered as being less destructive than RA, PsA is much more aggressive than previously thought. Essentially, about $20 \%$ of PsA patients develop a mutilating form of arthritis and $40-60 \%$ of PsA patients develop erosions in the first 2 years of the disease (6). Usually considered to be irreversible, bone erosion is a key outcome in inflammatory rheumatic diseases and correlates with disease severity and functional deterioration. The radiographic assessment of bone erosion is the « gold standard $\gg$ for diagnosis, in daily clinical practice as well as in randomized controlled clinical trials of disease-modifying antirheumatic drugs, but is challenging. The development of more sensitive and reproducible analysis using ultrasound, magnetic resonance imaging or high-resolution peripheral quantitative computer tomography would be a promising development for erosion detection and monitoring in daily clinical practice. Periarticular trabecular bone is also altered in RA likely with similar mechanisms involved in
TABLE 1 | Common features and differences in bone loss between SpA and RA.

\begin{tabular}{|c|c|c|}
\hline & $\begin{array}{l}\text { SpA } \\
\text { (AS, PsA, reactive } \\
\text { arthritis) }\end{array}$ & RA \\
\hline Erosions & $\begin{array}{l}\text { - DIP, PIP joints } \\
\text { - Evenly distributed } \\
\text { - Small, } \Omega \text { or } \\
\text { tubule-shaped } \\
\text { - Poorly demarcated } \\
\text { - Periarticular site } \\
\text { - Association with } \\
\text { enthesitis and } \\
\text { bone formation }\end{array}$ & $\begin{array}{l}\text { - MTP, MCP, PIP, and wrist } \\
\text { joints } \\
\text { - Radial sites } \\
\text { - U-shaped } \\
\text { - Neatly demarcated } \\
\text { - Joint margins } \\
\text { - No association with } \\
\text { enthesitis and } \\
\text { bone formation }\end{array}$ \\
\hline $\begin{array}{l}\text { Periarticular } \\
\text { osteopenia }\end{array}$ & - absent & $\begin{array}{l}\text { - May precede bone } \\
\text { erosion }\end{array}$ \\
\hline $\begin{array}{l}\text { Generalized } \\
\text { bone loss }\end{array}$ & $\begin{array}{l}\text { - Axial skeleton } \\
\text { - Vertebral fractures } \\
\text { - Association with ectopic } \\
\text { new bone formation }\end{array}$ & $\begin{array}{l}\text { - Axial and appendicular } \\
\text { skeleton } \\
\text { - Vertebral and non- } \\
\text { vertebral fractures } \\
\text { - No association with } \\
\text { ectopic new } \\
\text { bone formation }\end{array}$ \\
\hline $\begin{array}{l}\text { Bone } \\
\text { remodeling }\end{array}$ & - $\uparrow$ Bone resorption & $\begin{array}{l}\text { - } \uparrow \text { Bone resorption } \\
\text { - } \downarrow \text { bone formation }\end{array}$ \\
\hline
\end{tabular}

DIP, distal interphalangeal; MTP, metatarsophalangeal; MCP, metacarpophalangeal; PIP, proximal interphalangeal. RA erosions, Neatly demarcated and located at joint margins where the inflamed synovium is in direct contact with bone, erosions in RA are Ushaped and observed predominantly in metacarpophalangeal / metatarsophalangeal and proximal interphalangeal joints with a strong preponderance for radial sites; PSA erosion, Poorly demarcated, smaller in size and depth, $\Omega$ or tubule-shaped, and are more evenly distributed. They are located in the periarticular site in proximal and distal interphalangeal joints and are closely associated with bone formation.

generalized bone loss. Radiographic periarticular osteopenia is one of the earliest radiological manifestations and may precede bone erosion or joint space narrowing in RA (7). In contrast, it appears that there is no periarticular bone loss in early PsA (8).

Secondary systemic osteopenia or osteoporosis involving the axial and appendicular skeleton remote from synovial inflammation is an important co-morbidity in inflammatory rheumatic diseases. In effect, the prevalence of densitometric osteoporosis in RA patients is increased about two fold compared with the general population and is responsible for a risk of both vertebral and non-vertebral fractures (9). Although patients with $\mathrm{SpA}$ have radiographic evidence of ectopic new bone formation, many present evidences of marked osteopenia, and osteoporosis in the spine that is associated with a high prevalence of vertebral fractures-even in early axial SpA (10, 11). Inflammation is the major mechanism involved in bone loss in inflammatory rheumatic diseases. Proinflammatory cytokines increase osteoclast activation and subsequent bone resorption in both rheumatic disease types (12) but inhibit bone formation only in RA $(13,14)$. As a consequence, treatment with TNFblockers both in RA and SpA has been shown to improve skeletal remodeling $(15,16)$. Apart from inflammation, others factors play a role such as the adverse skeletal effects of corticosteroids used to treat these diseases and immobility, due to painful joints, muscle weakness, and spine ankylosis-although 
bone loss is observed well-before the development of spinal immobility (17-19).

\section{OSTEOCLAST DIFFERENTIATION AND FUNCTION IN INFLAMMATORY RHEUMATIC DISEASES}

Osteoclasts are responsible for bone erosion and have been identified at sites of focal erosion at the pannus-bone interface both in RA patients $(20,21)$ and animal models of arthritis (22-26). This role was definitively demonstrated by osteoclastdeficient mouse models of arthritis which were shown to be fully protected from bone erosion $(25,26)$. Osteoclasts are multinucleated bone resorbing cells which originate from the fusion of mononucleated cells belonging to the myeloid lineage in the presence of macrophage colonystimulating factor (M-CSF) and Receptor Activator of Nuclear factor- $\kappa \mathrm{B}$ Ligand (RANKL). Osteoclast formation is governed by a regulatory triad, the receptor activator of NF-кB (RANK), its ligand RANKL and a decoy receptor osteoprotegerin (OPG) also known as osteoclastogenesis inhibitory factor. OPG binds to RANKL hampering RANKRANKL interaction, though RANKL/OPG ratio determines osteoclast number, lifespan and activity. Activation of RANK on mononuclear osteoclast precursors initiates a transcriptional cascade culminating in osteoclast differentiation. Interestingly, transcription factors important for osteoclast differentiation are key regulators of immune responses-such as NF- $\mathrm{B}$ and nuclear factor of activated $\mathrm{T}$ cells cytoplasmic 1 (NFATc1). RANKL signaling in osteoclasts is strengthened by the synergistic activation of Immunoreceptor tyrosine-based activation motif (ITAM)-containing proteins, DNAXactivating protein of $12 \mathrm{kDa}$ (DAP12) and $\mathrm{Fc}$ gamma receptor $(\mathrm{FcR} \gamma)(27,28)$.

RANKL expression is high in synovial tissue from RA, PsA, and SpA peripheral joint disease patients (29-32). Treatment with non-biologic disease-modifying anti-rheumatic drugs (DMARDs) or glucocorticoids decreases the RANKL/OPG ratio in RA synovium and is satisfyingly associated with improved radiographic scores $(17,33)$. In addition, pharmacological inhibition of osteoclasts either by bisphosphonate zolendronic acid, or denosumab, a RANKL-specific monoclonal blocking antibody, also demonstrated some efficacy in impairing the progression of bone erosion in both arthritic mice and RA patients (34-38). However, these anti-resorptive drugs targeting osteoclasts are inadequate because they also alter physiological bone remodeling, necessitating the discovery of new targets.

\section{ROLE OF T CELLS IN OSTEOCLASTOGENESIS}

$\mathrm{T}$ cells have emerged as primary players through both direct and indirect mechanisms in the pathogenesis of bone loss in arthritis (39). Although osteoblasts, osteocytes and T cells express RANKL, the major RANKL-expressing cell subset in arthritic joints has been shown to be synovial fibroblasts [(39), (Figure 1)]. However, these cells express RANKL under the effect of interleukin-17 (IL-17) produced by T helper (Th) 17 cells (40). Congruent with this result, IL-17A promotes osteoclast precursor increase, bone resorption biomarker induction, and bone erosion $(41,42)$; its inhibition leads to improvement of inflammatory arthritis animal models $(24,43)$. Nevertheless, while IL-17A inhibition has demonstrated robust efficacy in SpA including PsA (44-46), it has shown only limited effect in the treatment of active RA (47-51).

IL-17-producing Th17 cells are the exclusive proosteoclastogenic Tcell subset while Th1 and Th2 subsets inhibit osteoclastogenesis through their respective canonical cytokines IFN- $\gamma$ and IL-4 (52). Similarly, regulatory $\mathrm{T}$ cells inhibit osteoclastogenesis through anti-inflammatory cytokines such as IL-10 and through cytotoxic T lymphocyte antigen 4 (CTLA4) signaling, a negative regulator of $\mathrm{T}$ cell activation $(47,49,50)$. The anti-erosive effect of abatacept, a CTLA4-Ig fusion protein efficacious in patients with RA and active PsA, underlines this effect. Deficiencies in regulatory $\mathrm{T}$ cell function and Th17/regulatory $\mathrm{T}$ cell imbalance have been identified in RA and psoriasis $(53,54)$. However, data on the presence and distribution of regulatory $\mathrm{T}$ cells in inflamed synovial tissue and on the effects of abatacept on regulatory $\mathrm{T}$ cell function are both limited and conflicting $(8,55-57)$.

\section{ACPA-MEDIATED BONE EROSION}

ACPA targets are citrullinated proteins-mainly fibrinogen, $\alpha$-enolase, and vimentin. Citrullination, a posttranslational conversion of arginine residues to citrulline performed by peptidylarginine deiminases, is a physiological process which can be pathologically triggered by smoking, a well-known risk factor for RA (58).

ACPA currently constitute the most specific serological marker for the diagnosis of RA and have been thereby included in the American College of Rheumatology (ACR)/European League Against Rheumatism (EULAR) 2010 RA classification criteria (59). ACPA are also a strong predictive factor for the development of bone erosion $(60,61)$ and can emerge long before the onset of synovitis during an initial preclinical phase of autoimmunity, which is either asymptomatic or only associated with arthralgia (62-65). Remarkably, the hypothesis that bone damage in RA precedes the clinical onset of disease is supported by the discovery of systemic bone loss and cortical bone erosion in a cohort of healthy ACPApositive individuals (5), suggesting that ACPA directly trigger bone loss.

ACPA mainly belong to the IgG subtype and thus are recognized by $\mathrm{Fc} \gamma \mathrm{R}$ on immune cells. It was therefore originally proposed that ACPA indirectly mediate bone loss through the enhanced production of TNF by monocytes / macrophages (66), but in recent years two groups have shown that ACPA also bind directly to citrullinated proteins on the surface of osteoclast precursors and directly enhance osteoclastogenesis 


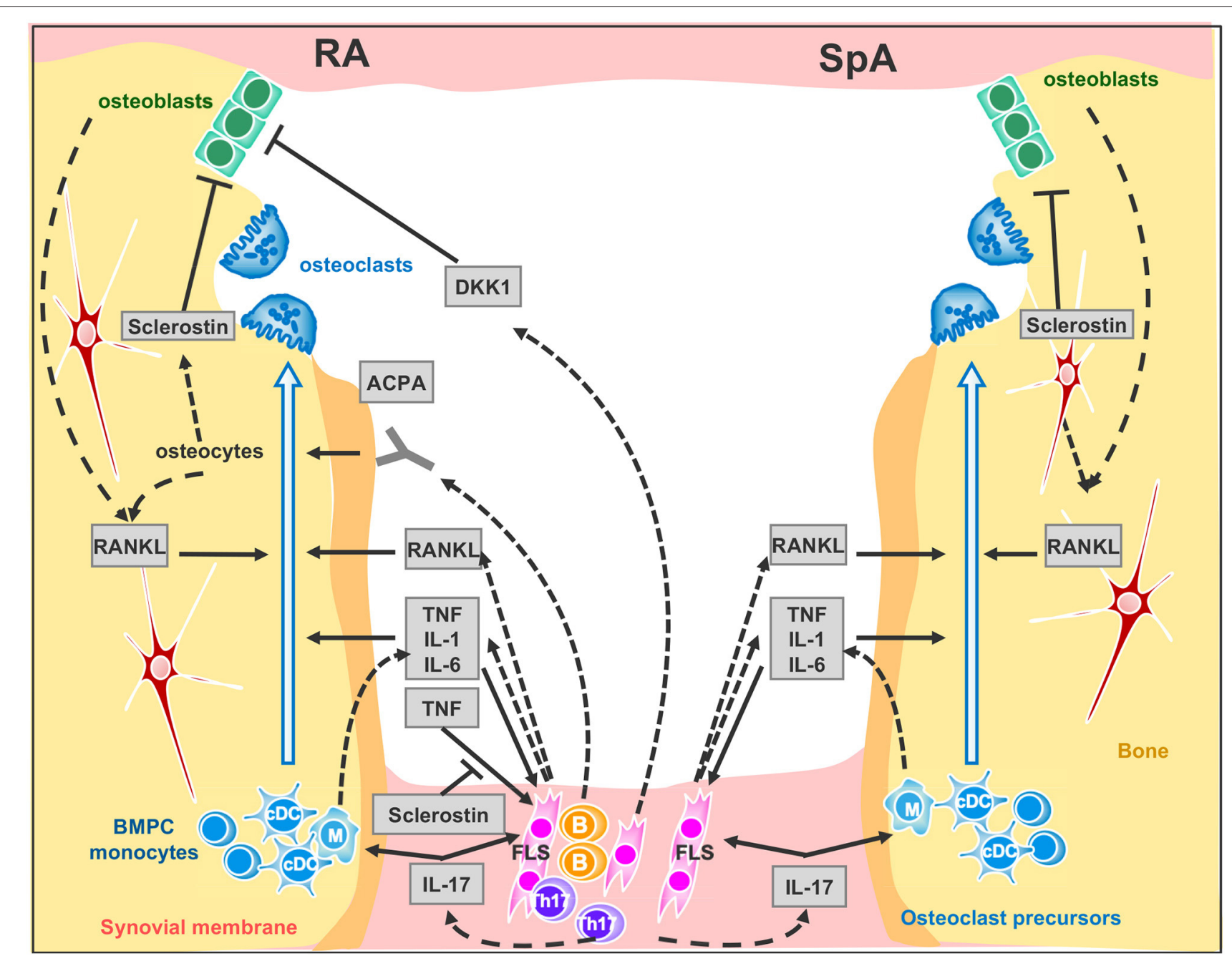

FIGURE 1 | Signaling network between synovial membrane and bone in inflammatory rheumatic disease. Left panel RA and right panel SpA cytokine signaling at inflamed joint. Plain arrows indicate an action of the cytokine, factor or auto-antibodies on the cells. Dotted arrows indicate cytokine, factor or auto-antibody production by the cells. ACPA, anti-citrullinated peptide antibodies; BMPC, bone marrow progenitor cells; DKK-1, Dickkopf-1; FLS, Fibroblast-like synoviocytes. B, B cells; Th17, Th17-cells; cDC, circulating dendritic cells. M, Macrophages.

(67, 68) (Figure 1). Remarkably, ACPA glycosylation patterns shift the change toward a more pro-inflammatory phenotype only within the 3 months prior to the onset of RA (69, 70). Furthermore, in newly differentiating antibody-producing cells, $\beta$-galactoside $\alpha 2,6$-sialyltransferase expression is regulated by Th17 cells in an IL-22- and IL-21- dependent manner, determining the glycosylation profile of IgG produced by plasma cells (70). Consequently, while IL-17 inhibition has a limited effect in the treatment of active RA, it may have a role when instituted at the early stages. Moreover, insofar as ACPA can promote bone resorption and some biologic DMARDs such as abatacept and rituximab (a monoclonal antibody against B cell CD20) can decrease ACPA levels in RA patients, the goal of achieving immunological remission with these treatments is enticing (71). However, the real value of reducing ACPA in RA patients still needs to be determined.
Taken together, these studies support a pathogenic role for ACPA in mediating bone loss in RA. In contrast, PsA is not frequently associated with circulating autoantibodies, including ACPA (72). This is probably the reason why rituximab, is effective in RA and not in PsA. However, when ACPA are present in PsA, titers are usually low but the disease phenotype is more severe with polyarticular involvement and erosive disease (73).

\section{PROINFLAMMATORY CYTOKINE-MEDIATED BONE RESORPTION}

Bone loss correlates well with disease activity and severity, supporting the current therapeutic strategy in inflammatory rheumatic diseases of targeting the best control of synovitis 
and the biological inflammatory syndrome. Indeed, conventional DMARDs, such as methotrexate, enable protection from bone erosion simply by their ability to reduce synovitis (74). However, some RA patients in sustained clinical remission or low disease activity still continue to accrue bone erosions $(38,75)$, likely because of subclinical synovial inflammation (76). This evolution is probably similar in SpA, but it has not yet been clearly demonstrated in the absence of well-defined remission criteria.

TNF overexpression is sufficient to induce arthritis in mice (77). TNF operates by several mechanisms: it promotes bone resorption indirectly in conjunction with IL- 6 by up-regulating RANKL expression in synovial fibroblasts $(78,79)$ and directly by aiding the differentiation of osteoclasts from mononuclear precursors in synovial tissues in synergy with RANKL (80) (Figure 1). Recent evidence suggests that combinations of cytokines, such as TNF plus IL-6, may drive RANK/RANKLindependent osteoclast formation (81) but this process still needs confirmation using other models. TNF also expands the pool of osteoclast precursor cells (82). Additionally, IL-1 is a mediator of TNF-induced osteoclastogenesis (83) while IL-6 is an important factor for Th17 differentiation. Accordingly, clinical trials-only in RA-with TNF blockers (16) and the Il-6 receptor blockade (84), have confirmed the impact of pro-inflammatory cytokines on osteoclastogenesis as they can retard or arrest the occurrence of bone erosion. As for the IL-1 blockade, despite having a limited effect on swelling, it protects from bone erosion in RA (85).

\section{OSTEOFORMATION AND EROSION REPAIR}

In RA only, the inflammatory milieu also impairs bone formation and erosion repair. TNF is the instrumental cytokine that unbalances bone homeostasis, blocking osteoblast differentiation and maturation through Wingless (Wnt) ligand signaling (86). Bone formation is governed by Wnt pathways which are critical for the osteoblast transcriptional differentiation program through the canonical $\beta$ catenin-dependent activation. The Wnt ligands interact with the membrane-bound co-receptor frizzled and the low-density lipoprotein receptor-related proteins LRP5 or LRP-6. This activated receptor complex stabilizes $\beta$ catenin transcription factor, allowing its translocation to the nucleus to directly coactivate Runx 2 and OPG $(87,88)$. In inflammatory rheumatic diseases, bone erosion repair is scarcely observed, even under biologic therapies such as TNF or IL-6 receptor blockers, and manifests only as apposition of new bone (sclerosis) at the base of the erosion $(89,90)$. Paradoxically, analysis of histological sections of arthritic samples, either from humans or from murine models, has shown the presence of osteoblast lineage cells close to the eroded bone once inflammation resolves $(21,91)$. In addition, intermittent parathyroid hormone (PTH) treatment an anabolic agent for bone- used for treatment of osteoporosis, fails to reduce erosion volume in patients with established RA with disease activity controlled by TNF blockers (92). By contrast to humans, treatment of hTNFtg mice with a combined therapy consisting of anti-TNF together with intermittent PTH led to regression of local bone erosion and bone repair, demonstrating new bone formation (93). An alternative to anabolic treatment aiming at increasing bone formation and repair, is to block bone formation antagonists. Indeed, Wnt pro-osteogenic function is controlled and tempered by several physiological antagonists: Dickkopf proteins (DKK-1 and 2), soluble frizzled-related proteins (sFRPs) $(94,95)$ and sclerostin that-in the presence of Wnt ligands-antagonizes LRP-6 internalization (96, 97). In RA, TNF lessens osteoformation by up-regulating DKK-1 expression, for instance DKK-1 level is found to be elevated in RA patients' sera and in hTNFtg mice, CIA, and GPIinduced arthritis mice, $(98,99)$. In hTNFtg mice only, DKK1 inhibition is able to prevent bone erosion and to promote bone formation, generating osteophytes around inflamed joints (99). Soluble frizzled-related proteins sFRP1 and sFRP2 are Wnt antagonist that sequestrate Wnt ligands, preventing them to activate frizzle/Lpr5 receptors, were also found elevated in synovial fluids of $\mathrm{KBxN}$ serum transfert inflammation induced mice model (91). Among the Wnt ligand antagonists, sclerostin is an attractive therapeutic target for bone loss pathologies. Sclerostin-neutralizing antibodies have been shown to have strong bone-building effects in mice, rats, monkeys, and humans (97-101). This treatment prevents the decrease of bone mineral density and bone volume at axial and appendicular sites in Collagen-Induced Arthritis mice but does not protect from erosion on the periarticular bone and fails to repair focal erosions (102). On the other hand, in hTNFtg mice, TNF induced sclerostin expression in inflammatory synoviocytes, unexpectedly, the absence of sclerostin in hTNFtg/ Sost ${ }^{-/-}$mice, instead of reversing the inflammatory bone destruction, elicited exacerbation of the disease. These observations suggest that sclerostin may be involved in regulating other pathways besides Wnt signaling or has an anti-osteoclastogenic effect in TNFdependent chronic arthritis (103). In line with this paradigm of uncovered sclerostin functions, recent findings surprisingly show that overexpressing sclerostin in murine skeletal stem cells forms overgrown bones when engrafted. This observation indicates that sclerostin could have an osteoforming effect on skeletal stem cells (104). Moreover, a recent study using non-inflammatory bone loss mouse models, unveiled a compensatory mechanism leading to increased expression of sclerostin when DKK-1 is inhibited. It would therefore perhaps be prudent before embarking upon antisclerostin treatments for RA, to conduct further studies in animal models of RA using Sost tissue-specific ablation to help obtain a better understanding of the precise role of sclerostin in chronic inflammatory diseases.

In contrast to RA, bone formation is observed in $\mathrm{SpA}$ at entheseal sites, resulting in endochondral bone formations. IL32 $\gamma$, among others pro-inflammatory cytokines, is found elevated in SpA synovial fluid, it is proposed that IL32 $\gamma$ enhances osteoblast differentiation via DKK-1 suppression, thereafter promoting abnormal bone formation (105). Indeed, lower levels of DKK-1 in AS and PsA patients and sclerostin in AS patients have been reported, potentially explaining the nonimpediment of osteoblast activity (99, 106, 107). In conflict with the above report, a recent meta-analysis showed no significant difference in sclerostin serum levels in AS and RA 
patients vs. healthy controls which suggests that sclerostin may not be associated with the pathogenesis of AS and RA (108). Last, a recent and challenging study revealed that vesicular RANK produced by mature osteoclasts stimulate early osteoblast differentiation through osteoblastic RANKL reverse signaling (109). Consequently, the development of a biological compound to trigger RANKL reverse signaling in osteoblast would be a new promising lead to promote bone formation.

\section{CONCLUSIONS}

In inflammatory rheumatic diseases, systemic and local bone loss constitute a common key outcome in terms of functional capacity and reflects the tight interaction between the immune system and bone, leading to an increase in osteoclast activity and a consequent uncoupling of bone resorption from formation. Once established, bone erosions are at present, still irreversible. It

\section{REFERENCES}

1. Horton JE, Raisz LG, Simmons HA, Oppenheim JJ, Mergenhagen SE. Bone resorbing activity in supernatant fluid from cultured human peripheral blood leukocytes. Science. (1972) 177:793-5.

2. Mundy GR, Raisz LG, Cooper RA, Schechter GP, Salmon SE. Evidence for the secretion of an osteoclast stimulating factor in myeloma. N Engl J Med. (1974) 291:1041-6. doi: 10.1056/NEJM197411142912001

3. Arron JR, Choi Y. Bone versus immune system. Nature. (2000) 408:535-6. doi: $10.1038 / 35046196$

4. Gravallese EM, Schett G. Effects of the IL-23-IL-17 pathway on bone in spondyloarthritis. Nat Rev Rheumatol. (2018) 14:631-40. doi: 10.1038/s41584-018-0091-8

5. Kleyer A, Finzel S, Rech J, Manger B, Krieter M, Faustini F, et al. Bone loss before the clinical onset of rheumatoid arthritis in subjects with anticitrullinated protein antibodies. Ann Rheum Dis. (2014) 73:854-60. doi: 10.1136/annrheumdis-2012-202958

6. Gladman DD, Antoni C, Mease P, Clegg DO, Nash P. Psoriatic arthritis: epidemiology, clinical features, course, and outcome. Ann Rheum Dis. (2005) 64 Suppl 2:ii14-7. doi: 10.1136/ard.2004.032482

7. Brower AC. Use of the radiograph to measure the course of rheumatoid arthritis. The gold standard versus fool's gold. Arthritis Rheum. (1990) 33:316-24.

8. Szentpetery A, Heffernan E, Haroon M, Kilbane M, Gallagher P, McKenna M), et al. Striking difference of periarticular bone density change in early psoriatic arthritis and rheumatoid arthritis following anti-rheumatic treatment as measured by digital X-ray radiogrammetry. Rheumatology. (2016) 55:891-6. doi: 10.1093/rheumatology/kev443

9. Haugeberg G, Uhlig T, Falch JA, Halse JI, Kvien TK. Bone mineral density and frequency of osteoporosis in female patients with rheumatoid arthritis: results from 394 patients in the Oslo County Rheumatoid Arthritis register. Arthritis Rheum. (2000) 43:522-30. doi: 10.1002/1529-0131(200003)43:3<522::AID-ANR7>3.0.CO;2-Y

10. van der Weijden MA, van Denderen JC, Lems WF, Heymans MW, Dijkmans BA, van der Horst-Bruinsma IE. Low bone mineral density is related to male gender and decreased functional capacity in early spondylarthropathies. Clin Rheumatol. (2011) 30:497-503. doi: 10.1007/s10067-010-1538-8

11. van der Weijden MA, van der Horst-Bruinsma IE, van Denderen JC, Dijkmans BA, Heymans MW, Lems WF. High frequency of vertebral fractures in early spondylarthropathies. Osteoporos Int. (2012) 23:1683-90. doi: 10.1007/s00198-011-1766-Z

12. Redlich K, Smolen JS. Inflammatory bone loss: pathogenesis and therapeutic intervention. Nat Rev Drug Discov. (2012) 11:234-50. doi: 10.1038/nrd3669 is to be hoped that a better future understanding of the molecular pathways involved in bone loss and bone formation-particularly in the context of inflammation-will enable the development of new therapies that can selectively and directly halt, or even repair, bone erosion.

\section{AUTHOR CONTRIBUTIONS}

All authors listed have made a substantial, direct and intellectual contribution to the work, and approved it for publication.

\section{FUNDING}

This work was supported by grants from INSERM and the University Claude Bernard Lyon-1 (OP), the Comité Départemental de la Loire de la Ligue Contre le Cancer (OP), the ANR grant LYSBONE (OP) (Grant n ${ }^{\circ}$ ANR-15-CE14-0010-01).
13. Bultink IE, Vis M, van der Horst-Bruinsma IE, Lems WF. Inflammatory rheumatic disorders and bone. Curr Rheumatol Rep. (2012) 14:224-30. doi: 10.1007/s11926-012-0252-8

14. Gao Y, Grassi F, Ryan MR, Terauchi M, Page K, Yang X, et al. IFN-gamma stimulates osteoclast formation and bone loss in vivo via antigen-driven $\mathrm{T}$ cell activation. J Clin Invest. (2007) 117:122-32. doi: 10.1172/JCI30074

15. Allali F, Breban M, Porcher R, Maillefert JF, Dougados M, Roux C. Increase in bone mineral density of patients with spondyloarthropathy treated with anti-tumour necrosis factor alpha. Ann Rheum Dis. (2003) 62:347-9. doi: 10.1136/ard.62.4.347

16. Vis M, Havaardsholm EA, Haugeberg G, Uhlig T, Voskuyl AE, van de Stadt RJ, et al. Evaluation of bone mineral density, bone metabolism, osteoprotegerin and receptor activator of the NFkappaB ligand serum levels during treatment with infliximab in patients with rheumatoid arthritis. Ann Rheum Dis. (2006) 65:1495-9. doi: 10.1136/ard.2005.044198

17. Hartmann K, Koenen M, Schauer S, Wittig-Blaich S, Ahmad M, Baschant $U$, et al. Molecular actions of glucocorticoids in cartilage and bone during health, disease, and steroid therapy. Physiol Rev. (2016) 96:409-47. doi: 10.1152/physrev.00011.2015

18. Mandl P, Kainberger F, Friberg Hitz M. Imaging in osteoporosis in rheumatic diseases. Best Pract Res Clin Rheumatol. (2016) 30:751-65. doi: $10.1016 /$ j.berh. 2016.08 .010

19. Boling EP. Secondary osteoporosis: underlying disease and the risk for glucocorticoid-induced osteoporosis. Clin Ther. (2004) 26:1-14.

20. Bromley M, Woolley DE. Chondroclasts and osteoclasts at subchondral sites of erosion in the rheumatoid joint. Arthritis Rheum. (1984) 27:968-75.

21. Gravallese EM, Harada Y, Wang JT, Gorn AH, Thornhill TS, Goldring SR. Identification of cell types responsible for bone resorption in rheumatoid arthritis and juvenile rheumatoid arthritis. Am J Pathol. (1998) 152:943-51.

22. Kong YY, Feige U, Sarosi I, Bolon B, Tafuri A, Morony S, et al. Activated $\mathrm{T}$ cells regulate bone loss and joint destruction in adjuvant arthritis through osteoprotegerin ligand. Nature. (1999) 402:304-9. doi: 10.1038/ 46303

23. Romas E, Sims NA, Hards DK, Lindsay M, Quinn JW, Ryan PF, et al. Osteoprotegerin reduces osteoclast numbers and prevents bone erosion in collagen-induced arthritis. Am J Pathol. (2002) 161:1419-27. doi: 10.1016/S0002-9440(10)64417-3

24. Lubberts E, Koenders MI, Oppers-Walgreen B, van den Bersselaar L, Coenen-de Roo CJ, Joosten LA, et al. Treatment with a neutralizing anti-murine interleukin-17 antibody after the onset of collageninduced arthritis reduces joint inflammation, cartilage destruction, and bone erosion. Arthritis Rheum. (2004) 50:650-9. doi: 10.1002/art. 20001 
25. Pettit AR, Ji H, von Stechow D, Muller R, Goldring SR, Choi Y, et al. TRANCE/RANKL knockout mice are protected from bone erosion in a serum transfer model of arthritis. Am J Pathol. (2001) 159:1689-99. doi: 10.1016/S0002-9440(10)63016-7

26. Redlich K, Hayer S, Ricci R, David JP, Tohidast-Akrad M, Kollias G, et al. Osteoclasts are essential for TNF-alpha-mediated joint destruction. J Clin Invest. (2002) 110:1419-27. doi: 10.1172/JCI15582

27. Mocsai A, Humphrey MB, Van Ziffle JA, Hu Y, Burghardt A, Spusta SC, et al. The immunomodulatory adapter proteins DAP12 and Fc receptor gamma-chain (FcRgamma) regulate development of functional osteoclasts through the Syk tyrosine kinase. Proc Natl Acad Sci USA. (2004) 101:6158-63. doi: 10.1073/pnas.0401602101

28. Koga $\mathrm{T}$, Inui $\mathrm{M}$, Inoue $\mathrm{K}$, Kim S, Suematsu A, Kobayashi E, et al. Costimulatory signals mediated by the ITAM motif cooperate with RANKL for bone homeostasis. Nature. (2004) 428:758-63. doi: 10.1038/nature02444

29. Crotti TN, Smith MD, Weedon H, Ahern MJ, Findlay DM, Kraan M, et al. Receptor activator NF-kappaB ligand (RANKL) expression in synovial tissue from patients with rheumatoid arthritis, spondyloarthropathy, osteoarthritis, and from normal patients: semiquantitative and quantitative analysis. Ann Rheum Dis. (2002) 61:1047-54. doi: 10.1136/ard.61.12.1047

30. Ritchlin CT, Haas-Smith SA, Li P, Hicks DG, Schwarz EM. Mechanisms of TNF-alpha- and RANKL-mediated osteoclastogenesis and bone resorption in psoriatic arthritis. J Clin Invest. (2003) 111:821-31. doi: 10.1172/JCI16069

31. Haynes DR, Barg E, Crotti TN, Holding C, Weedon H, Atkins GJ, et al. Osteoprotegerin expression in synovial tissue from patients with rheumatoid arthritis, spondyloarthropathies and osteoarthritis and normal controls. Rheumatology. (2003) 42:123-34. doi: 10.1093/rheumatology/keg047

32. van Tuyl LH, Voskuyl AE, Boers M, Geusens P, Landewe RB, Dijkmans $\mathrm{BA}$, et al. Baseline RANKL:OPG ratio and markers of bone and cartilage degradation predict annual radiological progression over 11 years in rheumatoid arthritis. Ann Rheum Dis. (2010) 69:1623-8. doi: 10.1136/ard.2009.121764

33. Haynes D, Crotti T, Weedon H, Slavotinek J, Au V, Coleman M, et al. Modulation of RANKL and osteoprotegerin expression in synovial tissue from patients with rheumatoid arthritis in response to disease-modifying antirheumatic drug treatment and correlation with radiologic outcome. Arthritis Rheum. (2008) 59:911-20. doi: 10.1002/art.23818

34. Jarrett SJ, Conaghan PG, Sloan VS, Papanastasiou P, Ortmann CE, O'Connor PJ, et al. Preliminary evidence for a structural benefit of the new bisphosphonate zoledronic acid in early rheumatoid arthritis. Arthritis Rheum. (2006) 54:1410-4. doi: 10.1002/art.21824

35. Herrak P, Gortz B, Hayer S, Redlich K, Reiter E, Gasser J, et al. Zoledronic acid protects against local and systemic bone loss in tumor necrosis factor-mediated arthritis. Arthritis Rheum. (2004) 50:2327-37. doi: 10.1002/art.20384

36. Sims NA, Green JR, Glatt M, Schlict S, Martin TJ, Gillespie MT, et al. Targeting osteoclasts with zoledronic acid prevents bone destruction in collagen-induced arthritis. Arthritis Rheum. (2004) 50:2338-46. doi: 10.1002/art.20382

37. Deodhar A, Dore RK, Mandel D, Schechtman J, Shergy W, Trapp R, et al. Denosumab-mediated increase in hand bone mineral density associated with decreased progression of bone erosion in rheumatoid arthritis patients. Arthritis Care Res. (2010) 62:569-74. doi: 10.1002/acr.20004

38. Cohen G, Gossec L, Dougados M, Cantagrel A, Goupille P, Daures JP, et al. Radiological damage in patients with rheumatoid arthritis on sustained remission. Ann Rheum Dis. (2007) 66:358-63. doi: 10.1136/ard.2006.057497

39. Danks L, Komatsu N, Guerrini MM, Sawa S, Armaka M, Kollias G, et al. RANKL expressed on synovial fibroblasts is primarily responsible for bone erosions during joint inflammation. Ann Rheum Dis. (2016) 75:1187-95. doi: 10.1136/annrheumdis-2014-207137

40. Kotake S, Udagawa N, Hakoda M, Mogi M, Yano K, Tsuda E, et al. Activated human $\mathrm{T}$ cells directly induce osteoclastogenesis from human monocytes: possible role of $\mathrm{T}$ cells in bone destruction in rheumatoid arthritis patients. Arthritis Rheum. (2001) 44:1003-12. doi: 10.1002/1529-0131(200105)44:5<1003::AID-ANR179>3.0.CO;2

41. Lubberts E, Oppers-Walgreen B, Pettit AR, Van Den Bersselaar L, Joosten LA, Goldring SR, et al. Increase in expression of receptor activator of nuclear factor kappaB at sites of bone erosion correlates with progression of inflammation in evolving collagen-induced arthritis. Arthritis Rheum. (2002) 46:3055-64. doi: 10.1002/art.10607

42. Adamopoulos IE, Suzuki E, Chao CC, Gorman D, Adda S, Maverakis E, et al. IL-17A gene transfer induces bone loss and epidermal hyperplasia associated with psoriatic arthritis. Ann Rheum Dis. (2015) 74:1284-92. doi: 10.1136/annrheumdis-2013-204782

43. Bush KA, Farmer KM, Walker JS, Kirkham BW. Reduction of joint inflammation and bone erosion in rat adjuvant arthritis by treatment with interleukin-17 receptor IgG1 Fc fusion protein. Arthritis Rheum. (2002) 46:802-5. doi: 10.1002/art.10173

44. McInnes IB, Mease PJ, Kirkham B, Kavanaugh A, Ritchlin CT, Rahman P, et al. Secukinumab, a human anti-interleukin-17A monoclonal antibody, in patients with psoriatic arthritis (FUTURE 2): a randomised, doubleblind, placebo-controlled, phase 3 trial. Lancet. (2015) 386:1137-46. doi: 10.1016/S0140-6736(15)61134-5

45. Mease PJ, McInnes IB, Kirkham B, Kavanaugh A, Rahman P, van der Heijde D, et al. Secukinumab Inhibition of Interleukin-17A in Patients with Psoriatic Arthritis. N Engl J Med. (2015) 373:1329-39. doi: 10.1056/NEJMoa14 12679

46. van der Heijde D, Gladman DD, Kishimoto M, Okada M, Rathmann SS, Moriarty SR, et al. Efficacy and Safety of Ixekizumab in Patients with Active Psoriatic Arthritis: 52-week Results from a Phase III Study (SPIRIT-P1). J Rheumatol. (2018) 45:367-77doi: 10.3899/jrheum. 170429

47. Hueber W, Patel DD, Dryja T, Wright AM, Koroleva I, Bruin G, et al. Effects of AIN457, a fully human antibody to interleukin-17A, on psoriasis, rheumatoid arthritis, and uveitis. Sci Transl Med. (2010) 2:52ra72. doi: 10.1126/scitranslmed.3001107

48. Genovese MC, Durez P, Richards HB, Supronik J, Dokoupilova E, Mazurov V, et al. Efficacy and safety of secukinumab in patients with rheumatoid arthritis: a phase II, dose-finding, double-blind, randomised, placebo controlled study. Ann Rheum Dis. (2013) 72:863-9. doi: 10.1136/annrheumdis-2012-201601

49. Genovese MC, Fleischmann R, Furst D, Janssen N, Carter J, Dasgupta B, et al. Efficacy and safety of olokizumab in patients with rheumatoid arthritis with an inadequate response to TNF inhibitor therapy: outcomes of a randomised Phase IIb study. Ann Rheum Dis. (2014) 73:1607-15. doi: 10.1136/annrheumdis-2013-204760

50. Tlustochowicz W, Rahman P, Seriolo B, Krammer G, Porter B, Widmer A, et al. Efficacy and safety of subcutaneous and intravenous loading dose regimens of secukinumab in patients with active rheumatoid arthritis: results from a randomized phase II study. J Rheumatol. (2016) 43:495-503. doi: 10.3899/jrheum.150117

51. Blanco FJ, Moricke R, Dokoupilova E, Codding C, Neal J, Andersson M, et al. Secukinumab in active rheumatoid arthritis: a phase III randomized, doubleblind, active comparator- and placebo-controlled study. Arthritis Rheumatol. (2017) 69:1144-53. doi: 10.1002/art.40070

52. Sato K, Suematsu A, Okamoto K, Yamaguchi A, Morishita Y, Kadono Y, et al. Th17 functions as an osteoclastogenic helper $\mathrm{T}$ cell subset that links $\mathrm{T}$ cell activation and bone destruction. J Exp Med. (2006) 203:2673-82. doi: 10.1084/jem.20061775

53. Flores-Borja F, Jury EC, Mauri C, Ehrenstein MR. Defects in CTLA-4 are associated with abnormal regulatory $\mathrm{T}$ cell function in rheumatoid arthritis. Proc Natl Acad Sci USA. (2008) 105:19396-401. doi: 10.1073/pnas.0806855105

54. Sugiyama H, Gyulai R, Toichi E, Garaczi E, Shimada S, Stevens $\mathrm{SR}$, et al. Dysfunctional blood and target tissue CD4+CD25high regulatory $\mathrm{T}$ cells in psoriasis: mechanism underlying unrestrained pathogenic effector T cell proliferation. J Immunol. (2005) 174:164-73. doi: 10.4049/jimmunol.174.1.164

55. Cao D, van Vollenhoven R, Klareskog L, Trollmo C, Malmstrom V. $\mathrm{CD} 25$ brightCD4+ regulatory $\mathrm{T}$ cells are enriched in inflamed joints of patients with chronic rheumatic disease. Arthritis Res Ther. (2004) 6:R33546. doi: 10.1186/ar1192

56. Bonelli M, Goschl L, Bluml S, Karonitsch T, Hirahara K, Ferner E, et al. Abatacept (CTLA-4Ig) treatment reduces $\mathrm{T}$ cell apoptosis and regulatory $\mathrm{T}$ cell suppression in patients with rheumatoid arthritis. Rheumatology. (2016) 55:710-20. doi: 10.1093/rheumatology/kev403 
57. Alvarez-Quiroga C, Abud-Mendoza C, Doniz-Padilla L, JuarezReyes A, Monsivais-Urenda A, Baranda L, et al. CTLA-4-Ig therapy diminishes the frequency but enhances the function of Treg cells in patients with rheumatoid arthritis. J Clin Immunol. (2011) 31:588-95. doi: $10.1007 /$ s10875-011-9527-5

58. Klareskog L, Stolt P, Lundberg K, Kallberg H, Bengtsson C, Grunewald J, et al. A new model for an etiology of rheumatoid arthritis: smoking may trigger HLA-DR (shared epitope)-restricted immune reactions to autoantigens modified by citrullination. Arthritis Rheum. (2006) 54:38-46. doi: $10.1002 /$ art. 21575

59. Aletaha D, Neogi T, Silman AJ, Funovits J, Felson DT, Bingham CO, 3rd, et al. 2010 rheumatoid arthritis classification criteria: an American College of Rheumatology/European League Against Rheumatism collaborative initiative. Ann Rheum Dis. (2010) 69:1580-8. doi: 10.1136/ard.2010.138461

60. Arkema EV, Goldstein BL, Robinson W, Sokolove J, Wagner CA, Malspeis S, et al. Anti-citrullinated peptide autoantibodies, human leukocyte antigen shared epitope and risk of future rheumatoid arthritis: a nested case-control study. Arthritis Res Ther. (2013) 15:R159. doi: 10.1186/ar4342

61. Jilani AA, Mackworth-Young CG. The role of citrullinated protein antibodies in predicting erosive disease in rheumatoid arthritis: a systematic literature review and meta-analysis. Int J Rheumatol. (2015) 2015:728610. doi: $10.1155 / 2015 / 728610$

62. Rantapaa-Dahlqvist S, de Jong BA, Berglin E, Hallmans G, Wadell G, Stenlund $\mathrm{H}$, et al. Antibodies against cyclic citrullinated peptide and IgA rheumatoid factor predict the development of rheumatoid arthritis. Arthritis Rheum. (2003) 48:2741-9. doi: 10.1002/art.11223

63. Nielen MM, van Schaardenburg D, Reesink HW, van de Stadt RJ, van der Horst-Bruinsma IE, de Koning MH, et al. Specific autoantibodies precede the symptoms of rheumatoid arthritis: a study of serial measurements in blood donors. Arthritis Rheum. (2004) 50:380-6. doi: 10.1002/art.20018

64. Wigerblad G, Bas DB, Fernades-Cerqueira C, Krishnamurthy A, Nandakumar KS, Rogoz K, et al. Autoantibodies to citrullinated proteins induce joint pain independent of inflammation via a chemokine-dependent mechanism. Ann Rheum Dis. (2016) 75:730-8. doi: 10.1136/annrheumdis-2015-208094

65. van der Woude D, Rantapaa-Dahlqvist S, Ioan-Facsinay A, Onnekink C, Schwarte CM, Verpoort KN, et al. Epitope spreading of the anti-citrullinated protein antibody response occurs before disease onset and is associated with the disease course of early arthritis. Ann Rheum Dis. (2010) 69:1554-61. doi: 10.1136/ard.2009.124537

66. Lu MC, Lai NS, Yu HC, Huang HB, Hsieh SC, Yu CL. Anticitrullinated protein antibodies bind surface-expressed citrullinated Grp78 on monocyte/macrophages and stimulate tumor necrosis factor alpha production. Arthritis Rheum. (2010) 62:1213-23. doi: 10.1002/art.27386

67. Harre U, Lang SC, Pfeifle R, Rombouts Y, Fruhbeisser S, Amara K, et al. Glycosylation of immunoglobulin $\mathrm{G}$ determines osteoclast differentiation and bone loss. Nat Commun. (2015) 6:6651. doi: 10.1038/ncomms7651

68. Krishnamurthy A, Joshua V, Haj Hensvold A, Jin T, Sun M, Vivar $\mathrm{N}$, et al. Identification of a novel chemokine-dependent molecular mechanism underlying rheumatoid arthritis-associated autoantibody-mediated bone loss. Ann Rheum Dis. (2016) 75:721-9. doi: 10.1136/annrheumdis-2015-208093

69. Rombouts Y, Ewing E, van de Stadt LA, Selman MH, Trouw LA, Deelder $\mathrm{AM}$, et al. Anti-citrullinated protein antibodies acquire a pro-inflammatory Fc glycosylation phenotype prior to the onset of rheumatoid arthritis. Ann Rheum Dis. (2015) 74:234-41. doi: 10.1136/annrheumdis-2013-203565

70. Pfeifle R, Rothe T, Ipseiz N, Scherer HU, Culemann S, Harre U, et al. Regulation of autoantibody activity by the IL-23-TH17 axis determines the onset of autoimmune disease. Nat Immunol. (2017) 18:104-13. doi: 10.1038/ni.3579

71. Wunderlich C, Oliviera I, Figueiredo CP, Rech J, Schett G. Effects of DMARDs on citrullinated peptide autoantibody levels in RA patientsA longitudinal analysis. Semin Arthritis Rheum. (2017) 46:709-14. doi: 10.1016/j.semarthrit.2016.09.011

72. Alenius GM, Berglin E, Rantapaa Dahlqvist S. Antibodies against cyclic citrullinated peptide (CCP) in psoriatic patients with or without joint inflammation. Ann Rheum Dis. (2006) 65:398-400. doi: 10.1136/ard.2005.040998
73. Perez-Alamino R, Garcia-Valladares I, Cuchacovich R, Iglesias-Gamarra A, Espinoza LR. Are anti-CCP antibodies in psoriatic arthritis patients a biomarker of erosive disease? Rheumatol Int. (2014) 34:1211-6. doi: 10.1007/s00296-014-2956-8

74. Rich E, Moreland LW, Alarcon GS. Paucity of radiographic progression in rheumatoid arthritis treated with methotrexate as the first disease modifying antirheumatic drug. J Rheumatol. (1999) 26:259-61.

75. Molenaar ET, Voskuyl AE, Dinant HJ, Bezemer PD, Boers M, Dijkmans BA. Progression of radiologic damage in patients with rheumatoid arthritis in clinical remission. Arthritis Rheum. (2004) 50:36-42. doi: 10.1002/art.11481

76. Brown AK, Conaghan PG, Karim Z, Quinn MA, Ikeda K, Peterfy CG, et al. An explanation for the apparent dissociation between clinical remission and continued structural deterioration in rheumatoid arthritis. Arthritis Rheum. (2008) 58:2958-67. doi: 10.1002/art.23945

77. Keffer J, Probert L, Cazlaris H, Georgopoulos S, Kaslaris E, Kioussis D, et al. Transgenic mice expressing human tumour necrosis factor: a predictive genetic model of arthritis. EMBO J. (1991) 10:4025-31.

78. Tunyogi-Csapo M, Kis-Toth K, Radacs M, Farkas B, Jacobs JJ, Finnegan A, et al. Cytokine-controlled RANKL and osteoprotegerin expression by human and mouse synovial fibroblasts: fibroblast-mediated pathologic bone resorption. Arthritis Rheum. (2008) 58:2397-408. doi: 10.1002/art. 23653

79. Hashizume M, Hayakawa N, Mihara M. IL-6 trans-signalling directly induces RANKL on fibroblast-like synovial cells and is involved in RANKL induction by TNF-alpha and IL-17. Rheumatology. (2008) 47:1635-40. doi: 10.1093/rheumatology/ken363

80. Lam J, Takeshita S, Barker JE, Kanagawa O, Ross FP, Teitelbaum SL. TNF-alpha induces osteoclastogenesis by direct stimulation of macrophages exposed to permissive levels of RANK ligand. J Clin Invest. (2000) 106:14818. doi: $10.1172 / \mathrm{JCI} 11176$

81. Yokota K, Sato K, Miyazaki T, Kitaura H, Kayama H, Miyoshi F, et al. Combination of tumor necrosis factor alpha and interleukin- 6 induces mouse osteoclast-like cells with bone resorption activity both in vitro and in vivo. Arthritis Rheumatol. (2014) 66:121-9. doi: 10.1002/art. 38218

82. Yao Z, Li P, Zhang Q, Schwarz EM, Keng P, Arbini A, et al. Tumor necrosis factor-alpha increases circulating osteoclast precursor numbers by promoting their proliferation and differentiation in the bone marrow through up-regulation of c-Fms expression. J Biol Chem. (2006) 281:1184655. doi: $10.1074 / j b c . M 512624200$

83. Wei S, Kitaura H, Zhou P, Ross FP, Teitelbaum SL. IL-1 mediates TNF-induced osteoclastogenesis. J Clin Invest. (2005) 115:282-90. doi: $10.1172 / \mathrm{JCI} 23394$

84. Nishimoto N, Hashimoto J, Miyasaka N, Yamamoto K, Kawai S, Takeuchi T, et al. Study of active controlled monotherapy used for rheumatoid arthritis, an IL-6 inhibitor (SAMURAI): evidence of clinical and radiographic benefit from an $\mathrm{x}$ ray reader-blinded randomised controlled trial of tocilizumab. Ann Rheum Dis. (2007) 66:1162-7. doi: 10.1136/ard.2006.0 68064

85. Jiang Y, Genant HK, Watt I, Cobby M, Bresnihan B, Aitchison R, et al. A multicenter, double-blind, dose-ranging, randomized, placebocontrolled study of recombinant human interleukin-1 receptor antagonist in patients with rheumatoid arthritis: radiologic progression and correlation of Genant and Larsen scores. Arthritis Rheum. (2000) 43:1001-9. doi: 10.1002/1529-0131(200005)43:5<1001::AID-ANR7>3.0.CO;2-P

86. Findlay DM, Atkins GJ. TWEAK and TNF regulation of sclerostin: a novel pathway for the regulation of bone remodelling. Adv Exp Med Biol. (2011) 691:337-48doi: 10.1007/978-1-4419-6612-4_34

87. Holmen SL, Giambernardi TA, Zylstra CR, Buckner-Berghuis BD, Resau $\mathrm{JH}$, Hess JF, et al. Decreased BMD and limb deformities in mice carrying mutations in both Lrp5 and Lrp6. J Bone Miner Res. (2004) 19:2033-40. doi: 10.1359/JBMR.040907

88. Hu H, Hilton MJ, Tu X, Yu K, Ornitz DM, Long F. Sequential roles of Hedgehog and Wnt signaling in osteoblast development. Development. (2005) 132:49-60. doi: 10.1242/dev.01564

89. Finzel S, Englbrecht M, Engelke K, Stach C, Schett G. A comparative study of periarticular bone lesions in rheumatoid arthritis and psoriatic arthritis. Ann Rheum Dis. (2011) 70:122-7. doi: 10.1136/ard.2010.132423 
90. Finzel S, Rech J, Schmidt S, Engelke K, Englbrecht M, Schett G. Interleukin-6 receptor blockade induces limited repair of bone erosions in rheumatoid arthritis: a micro CT study. Ann Rheum Dis. (2013) 72:396-400. doi: 10.1136/annrheumdis-2011-201075

91. Matzelle MM, Gallant MA, Condon KW, Walsh NC, Manning CA, Stein GS, et al. Resolution of inflammation induces osteoblast function and regulates the Wnt signaling pathway. Arthritis Rheum. (2012) 64:1540-50. doi: 10.1002/art.33504

92. Solomon DH, Kay J, Duryea J, Lu B, Bolster MB, Yood RA, et al. Effects of teriparatide on joint erosions in rheumatoid arthritis: a randomized controlled trial. Arthritis Rheumatol. (2017) 69:1741-50. doi: 10.1002/art.40156

93. Redlich K, Gortz B, Hayer S, Zwerina J, Doerr N, Kostenuik P, et al. Repair of local bone erosions and reversal of systemic bone loss upon therapy with anti-tumor necrosis factor in combination with osteoprotegerin or parathyroid hormone in tumor necrosis factor-mediated arthritis. Am J Pathol. (2004) 164:543-55. doi: 10.1016/S0002-9440(10)63144-6

94. Ai M, Holmen SL, Van Hul W, Williams BO, Warman ML. Reduced affinity to and inhibition by DKK1 form a common mechanism by which high bone mass-associated missense mutations in LRP5 affect canonical Wnt signaling. Mol Cell Biol. (2005) 25:4946-55. doi: 10.1128/MCB.25.12.4946-49 55.2005

95. Bourhis E, Wang W, Tam C, Hwang J, Zhang Y, Spittler D, et al. Wnt antagonists bind through a short peptide to the first beta-propeller domain of LRP5/6. Structure. (2011) 19:1433-42. doi: 10.1016/j.str.2011. 07.005

96. Binnerts ME, Kim KA, Bright JM, Patel SM, Tran K, Zhou M, et al. RSpondin1 regulates Wnt signaling by inhibiting internalization of LRP6. Proc Natl Acad Sci USA. (2007) 104:14700-5. doi: 10.1073/pnas.0702 305104

97. Kedlaya R, Veera S, Horan DJ, Moss RE, Ayturk UM, Jacobsen CM, et al. Sclerostin inhibition reverses skeletal fragility in an Lrp5-deficient mouse model of OPPG syndrome. Sci Transl Med. (2013) 5:211ra158. doi: 10.1126/scitranslmed.3006627

98. Ma Y, Zhang X, Wang M, Xia Q, Yang J, Wu M, et al. The serum level of Dickkopf-1 in patients with rheumatoid arthritis: a systematic review and meta-analysis. Int Immunopharmacol. (2018) 59:227-32. doi: 10.1016/j.intimp.2018.04.019

99. Diarra D, Stolina M, Polzer K, Zwerina J, Ominsky MS, Dwyer D, et al. Dickkopf-1 is a master regulator of joint remodeling. Nat Med. (2007) 13:156-63. doi: 10.1038/nm1538

100. Ominsky MS, Vlasseros F, Jolette J, Smith SY, Stouch B, Doellgast G, et al. Two doses of sclerostin antibody in cynomolgus monkeys increases bone formation, bone mineral density, and bone strength. J Bone Miner Res. (2010) 25:948-59. doi: 10.1002/jbmr.14
101. Cosman F, Crittenden DB, Adachi JD, Binkley N, Czerwinski E, Ferrari S, et al. Romosozumab Treatment in Postmenopausal Women with Osteoporosis. N Engl J Med. (2016) 375:1532-43. doi: 10.1056/NEJMoa1607948

102. Marenzana M, Vugler A, Moore A, Robinson M. Effect of sclerostinneutralising antibody on periarticular and systemic bone in a murine model of rheumatoid arthritis: a microCT study. Arthritis Res Ther. (2013) 15:R125. doi: 10.1186/ar4305

103. Wehmeyer C, Frank S, Beckmann D, Bottcher M, Cromme C, Konig $U$, et al. Sclerostin inhibition promotes TNF-dependent inflammatory joint destruction. Sci Transl Med. (2016) 8:330ra35. doi: 10.1126/scitranslmed.aac4351

104. Chan CKF, Gulati GS, Sinha R, Tompkins JV, Lopez M, Carter AC, et al. Identification of the human skeletal stem cell. Cell. (2018) 175:43-56 e21. doi: 10.1016/j.cell.2018.07.029

105. Lee EJ, Lee EJ, Chung YH, Song DH, Hong S, Lee CK, et al. High level of interleukin-32 gamma in the joint of ankylosing spondylitis is associated with osteoblast differentiation. Arthritis Res Ther. (2015) 17:350. doi: 10.1186/s13075-015-0870-4

106. Appel H, Ruiz-Heiland G, Listing J, Zwerina J, Herrmann M, Mueller R, et al. Altered skeletal expression of sclerostin and its link to radiographic progression in ankylosing spondylitis. Arthritis Rheum. (2009) 60:3257-62. doi: 10.1002/art.24888

107. Fassio A, Idolazzi L, Viapiana O, Benini C, Vantaggiato E, Bertoldo F, et al. In psoriatic arthritis Dkk-1 and PTH are lower than in rheumatoid arthritis and healthy controls. Clin Rheumatol. (2017) 36:237781. doi: $10.1007 /$ s10067-017-3734-2

108. Shi J, Ying H, Du J, Shen B. Serum sclerostin levels in patients with ankylosing spondylitis and rheumatoid arthritis: a systematic review and meta-analysis. Biomed Res Int. (2017) 2017:9295313. doi: 10.1155/2017/9295313

109. Ikebuchi Y, Aoki S, Honma M, Hayashi M, Sugamori Y, Khan M, et al. Coupling of bone resorption and formation by RANKL reverse signalling Nature. (2018) 561:195-200. doi: 10.1038/s41586-018-0482-7

Conflict of Interest Statement: The authors declare that the research was conducted in the absence of any commercial or financial relationships that could be construed as a potential conflict of interest.

Copyright (c) 2019 Coury, Peyruchaud and Machuca-Gayet. This is an open-access article distributed under the terms of the Creative Commons Attribution License (CC $B Y)$. The use, distribution or reproduction in other forums is permitted, provided the original author(s) and the copyright owner(s) are credited and that the original publication in this journal is cited, in accordance with accepted academic practice. No use, distribution or reproduction is permitted which does not comply with these terms. 